\title{
Metric-Dependent Tendency of Tropical Belt Width Changes during the Last Glacial Maximum
}

\author{
NA WANG \\ Institute of Atmospheric Physics, Chinese Academy of Sciences, and University of Chinese Academy of Sciences, Beijing, China
}

\section{DABANG JIANG}

Institute of Atmospheric Physics, Chinese Academy of Sciences, Beijing, and Joint Laboratory for Climate and Environmental Change, Chengdu University of Information Technology, Chengdu, and Center for Excellence in Tibetan Plateau Earth Sciences, Chinese Academy of Sciences, Beijing, and Collaborative Innovation Center on Forecast and Evaluation of Meteorological Disasters, Nanjing University of Information Science and Technology, Nanjing, and University of Chinese Academy of Sciences, Beijing, China

\section{XIANMEI LANG}

Institute of Atmospheric Physics, Chinese Academy of Sciences, Beijing, and Center for Excellence in Tibetan Plateau Earth Sciences, Chinese Academy of Sciences, Beijing, and Collaborative Innovation Center on Forecast and Evaluation of Meteorological Disasters, Nanjing University of Information Science and Technology, Nanjing, China

(Manuscript received 2 April 2018, in final form 25 July 2018)

\begin{abstract}
Motivated by studies of tropical expansion under modern global warming, the behavior of the tropical belt during the Last Glacial Maximum (LGM) relative to the preindustrial period has been investigated in this study, using simulations from phase 3 of the Paleoclimate Modelling Intercomparison Project (PMIP3) under the framework of phase 5 of the Coupled Model Intercomparison Project (CMIP5). The tropical belt width changes determined by multiple metrics present two opposite tendencies. One refers to the poleward migration of the tropical edge as measured by the steep tropopause gradient and the subtropical jet, and the other suggests that the LGM tropics become narrower as measured by the Hadley cell extent, the eddy-driven jet, and the latitude where precipitation minus evaporation equals zero. The magnitude of such changes widely differs across models and metrics. In absolute terms, the multimodel mean total width changes range from $0.6^{\circ}$ to $1.7^{\circ}$ among metrics, with contributions predominantly from the Northern Hemisphere. Furthermore, the two metrics that indicate tropical widening are located in the upper troposphere. Such widening is closely related to the vertical and meridional temperature gradient changes in the subtropical regions. The other metrics are located in the middle and lower troposphere, and their variations are directly or indirectly related to changes in the low-level baroclinicity. The diverse responses of metrics to the LGM boundary conditions suggest that the tropical belt width changes and their climatic impacts are distinguished by the different measurements. The selection of metrics should correspond to the specific tropical properties of concern.
\end{abstract}

\section{Introduction}

On the rotating and differentially heated Earth, the tropical atmospheric circulation is distinguished from that in the extratropical regions, giving rise to the meridional demarcation of climate properties. Although the boundaries of the tropics are not uniquely defined, numerous observational studies based on independent diagnostics have suggested that the tropical belt has

Corresponding author: Dabang Jiang, jiangdb@mail.iap.ac.cn been widening since at least the late 1970s. These pieces of evidence include the broadening Hadley cell and associated changes in the outgoing longwave radiation ( $\mathrm{Hu}$ and $\mathrm{Fu} 2007)$, the expansion of the subtropical dry zone (Zhou et al. 2011), the rise of the subtropical tropopause height (Seidel and Randel 2007; Lucas et al. 2012), and the poleward shift of jet streams and storm tracks (McCabe et al. 2001; Fu et al. 2006; Archer and Caldeira 2008). Such widening of the tropical belt was estimated as $0.25^{\circ}-3^{\circ}$ decade $^{-1}$ (Davis and Rosenlof 2012), with potential influences on local 
water resources, the ecological environment, and economic development.

Model simulations have been widely used to provide the possible causes and underlying mechanisms of this observed trend. Based on the historical individual forcing experiments from phase 5 of the Coupled Model Intercomparison Project (CMIP5), Tao et al. (2016) attributed the observed expansion of the Hadley cell to increasing greenhouse gas (GHG) concentrations and stratospheric ozone depletion. In the Southern Hemisphere ( $\mathrm{SH})$, stratospheric ozone depletion is considered to be the main driver of the tropospheric circulation changes over the second half of the twentieth century, especially during the austral summer (Son et al. 2009; Polvani et al. 2011; Min and Son 2013). The influence of anthropogenic aerosols on the Northern Hemisphere $(\mathrm{NH})$ tropical expansion has also been reported (Allen et al. 2012; Allen and Ajoku 2016), but there are considerable uncertainties because of the estimated aerosol emission and its radiative effect (Bond et al. 2013; Wilcox et al. 2013).

In addition to anthropogenic forcing, more attention has been drawn to the role of natural variability in recent tropical expansion (Adam et al. 2014; Allen et al. 2014; Allen and Kovilakam 2017; Mantsis et al. 2017), with a focus on the sea surface temperature pattern evolution related to El Niño-Southern Oscillation (ENSO) and the Pacific decadal oscillation (PDO). The annual-mean Hadley cell extent is significantly correlated with the ENSO index, expanding during the cold phases and contracting during the warm phases (Nguyen et al. 2013). On the decadal time scale, the tendency of the PDO toward more frequent occurrences of the negative phase was considered to explain the rapid tropical widening in the late 1990s (Grassi et al. 2012). Regionally, the PDO may account for approximately $50 \%$ of the observed Asian tropical expansion since 1979 (Lucas and Nguyen 2015).

Despite these well-documented influence factors, the cause of variation in the modern tropical belt width still remains unclear. The Last Glacial Maximum (LGM; approximately 21000 calendar years before present) was a glacial period featuring expanded ice sheets and lowered GHG concentrations. As the opposite of modern global warming, the response of the tropical belt width to the LGM climate is of great significance to our understanding of present and future tropical expansion. Recent studies about the simulated Hadley cell from the LGM to future climate suggest that the Hadley cell widens as the climate warms, and the extent is strongly correlated with variations in the subtropical static stability (D'Agostino et al. 2017; Son et al. 2018). Except for the Hadley cell, the behavior of the LGM tropical edges measured by other metrics is unknown. Do these metrics indicate a consistent tropical contraction as measured by the Hadley cell? What are the related mechanisms responsible for the changes in the LGM tropical belt width? To address the above questions, we systematically examine the LGM tropical edge changes by multiple diagnostics, using the state-of-the-art simulations archived from phase 3 of the Paleoclimate Modelling Intercomparison Project (PMIP3)/CMIP5.

In the following section, the model data and methods used to determine the tropical edge are briefly described. Section 3 presents an evaluation of the model performance. Section 4 presents the LGM tropical edge changes, and their relationship to the glacial thermal redistribution is discussed in section 5. Finally, section 6 summarizes our findings.

\section{Data and methods}

We use all available nine model outputs from the PMIP3/CMIP5 LGM and preindustrial experiments in this study, as detailed in Table 1. Both the LGM and preindustrial simulations are prescribed with nonevolving boundary conditions, according to the coordinated PMIP3-CMIP5 protocol (Taylor et al. 2012). The LGM boundary conditions compared to those of the preindustrial period are characterized by remarkable changes in the ice sheet extent and GHG concentrations. In particular, the atmospheric concentrations of $\mathrm{CO}_{2}, \mathrm{CH}_{4}$, and $\mathrm{N}_{2} \mathrm{O}$ are reduced from 280 to $185 \mathrm{ppmv}$, from 760 to $350 \mathrm{ppbv}$, and from 270 to $200 \mathrm{ppbv}$, respectively. Note that the orbital parameters are also altered in the LGM experiments, but their radiative forcings are trivial compared to the former two factors. For each simulation, the last 100 years were averaged to represent the climatological mean state of this period. The modern reanalyses from the European Centre for Medium-Range Weather Forecasts interim reanalysis (ERA-Interim) (Dee et al. 2011), the National Centers for Environmental Prediction-National Center for Atmospheric Research (NCEP-NCAR) 40-Year Reanalysis (Kalnay et al. 1996), NCEP-Department of Energy (NCEP-DOE) AMIP-II Reanalysis (Kanamitsu et al. 2002), and the National Aeronautics and Space Administration (NASA)'s Modern-Era Retrospective Analysis for Research and Applications (MERRA) (Rienecker et al. 2011) for the period of 1979-2008 are also used for model evaluation. To make an intermodel comparison and to determine the tropical edge at a finer scale, data from different sources are interpolated to an identical horizontal resolution of $0.5^{\circ} \times 0.5^{\circ}$. We also considered the topographic effect of LGM ice sheets on the spatial distributions of the meteorological variables; that is, for each 
TABLE 1. Basic information about the nine PMIP3/CMIP5 models used in this study.

\begin{tabular}{|c|c|c|}
\hline Model ID (acronym) & Institute & Atmospheric resolution \\
\hline CCSM4 (CCSM4) & NCAR, Boulder, Colorado & $1.25^{\circ} \times \sim 0.9^{\circ}, \mathrm{L} 26$ \\
\hline CNRM-CM5 (CNRM) & $\begin{array}{l}\text { Centre National de Recherches } \\
\text { Météorologiques, Météo-France, } \\
\text { Toulouse, France; Centre Europeen de } \\
\text { Recherches et de Formation Avancee } \\
\text { en Calcul Scientifique, Toulouse, } \\
\text { France }\end{array}$ & $\sim 1.4^{\circ} \times 1.4^{\circ}, \mathrm{L} 31$ \\
\hline COSMOS-ASO (COSMOS) & $\begin{array}{l}\text { Institute of Meteorology, Freie } \\
\text { Universität Berlin, Berlin, Germany }\end{array}$ & $3.75^{\circ} \times 3.75^{\circ}, \mathrm{L} 19$ \\
\hline FGOALS-g2.0 (FGOALS) & $\begin{array}{l}\text { Institute of Atmospheric Physics, Chinese } \\
\text { Academy of Sciences, Beijing, China; } \\
\text { Tsinghua University, Beijing, China }\end{array}$ & $\sim 2.8^{\circ} \times 3^{\circ}, \mathrm{L} 26$ \\
\hline GISS-E2-R (GISS) & $\begin{array}{l}\text { NASA Goddard Institute for Space } \\
\text { Studies, New York, New York }\end{array}$ & $2.5^{\circ} \times 2^{\circ}, \mathrm{L} 40$ \\
\hline IPSL-CM5A-LR (IPSL) & $\begin{array}{l}\text { L'Institut Pierre-Simon Laplace, Paris, } \\
\text { France }\end{array}$ & $3.75^{\circ} \times \sim 1.9^{\circ}, \mathrm{L} 39$ \\
\hline MIROC-ESM (MIROC) & $\begin{array}{l}\text { Japan Agency for Marine-Earth Science } \\
\text { and Technology, Kanagawa, Japan; } \\
\text { Atmosphere and Ocean Research } \\
\text { Institute, The University of Tokyo, } \\
\text { Chiba, Japan; National Institute for } \\
\text { Environmental Studies, Ibaraki, Japan }\end{array}$ & $\sim 2.8^{\circ} \times 2.8^{\circ}, \mathrm{L} 80$ \\
\hline MPI-ESM-P (MPI) & $\begin{array}{l}\text { Max Planck Institute for Meteorology, } \\
\text { Hamburg, Germany }\end{array}$ & $1.875^{\circ} \times 1.875^{\circ}, \mathrm{L} 47$ \\
\hline MRI-CGCM3 (MRI) & $\begin{array}{l}\text { Meteorological Research Institute, } \\
\text { Tsukuba, Japan }\end{array}$ & $1.125^{\circ} \times 1.125^{\circ}, \mathrm{L} 48$ \\
\hline
\end{tabular}

pressure level below $500 \mathrm{hPa}$, meteorological variables with a surface pressure higher than the pressure of the given level are set to missing values.

The metrics used to indicate tropical edge changes are based on the zonal-mean distribution of the mean meridional streamfunction (MMS), tropopause pressure (TP), zonal wind $U$ at levels of 200 and $850 \mathrm{hPa}$, and precipitation minus evaporation $(P-E)$, as shown in Fig. 1. In detail, they are measured by 1 ) the latitude where the MMS becomes zero at the poleward side of the subtropical maximum, which serves as the boundary of the Hadley cell; 2) the latitude of the maximum meridional TP gradient, which captures the abrupt reduction in tropopause height from the tropics to the extratropical regions; 3 ) the latitude of maximum $U$ at $200 \mathrm{hPa}$ (Jet200), used to identify the subtropical jet; 4) the latitude of maximum $U$ at $850 \mathrm{hPa}$ (Jet850), used to identify the eddy-driven jet; and 5) the latitude where the $P-E$ becomes zero at the poleward side of the subtropical minimum, which is also the poleward edge of the subtropical dry zone. It should be noted that the eddy-driven jet is located at the middle latitudes, rather than a component of the tropical atmospheric circulations. Previous studies have suggested its strong correlations and dynamical connections with other tropical metrics (Kang and Polvani 2011; Solomon et al. 2016;
Davis and Birner 2017); thus, we use it as indirect evidence to demonstrate changes in the tropical belt width.

The zero-crossing latitude is calculated by the linear interpolation between two adjacent grid points with

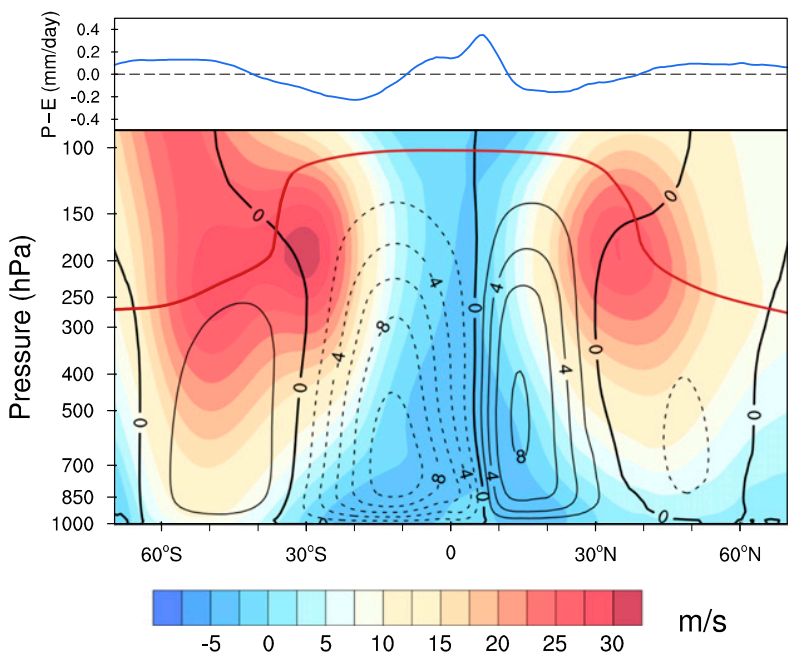

FIG. 1. The annual-mean zonal-mean distribution of atmospheric variables used to measure the tropical edge from ERA-Interim for 1979-2008, including the MMS (black contour; contour interval is $10^{10} \mathrm{~kg} \mathrm{~s}^{-1}$ ), TP (red curve), $U$ (color shading), and $P-E$ (blue curve). 


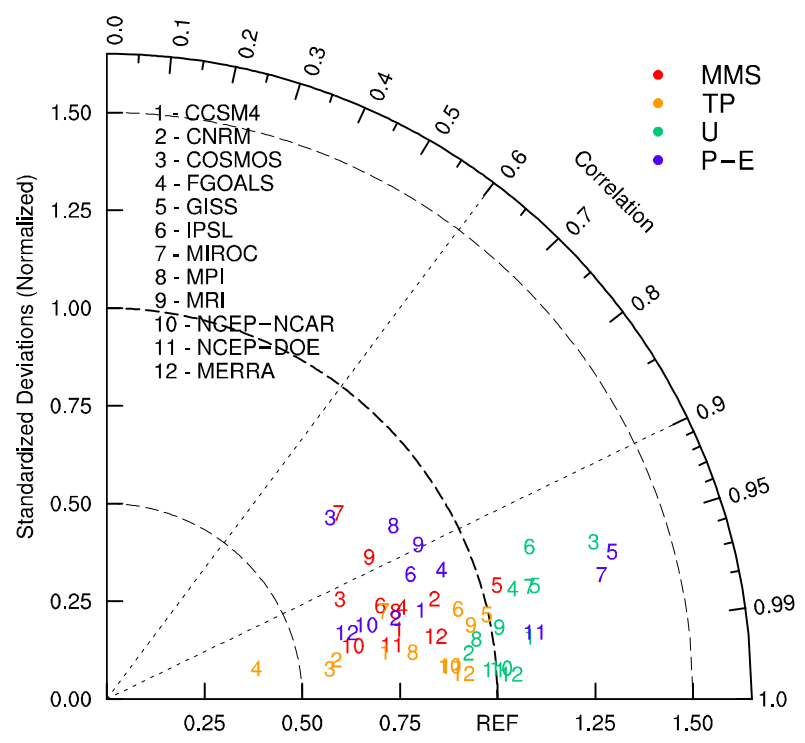

FIG. 2. Normalized Taylor diagram for comparing the spatial patterns of annual-mean zonal-mean $\left(60^{\circ} \mathrm{N}-60^{\circ} \mathrm{S}\right)$ MMS (red), TP (orange), $U$ (green), and $P-E$ (purple) from the PMIP3/CMIP5 preindustrial experiments and other reanalyses (data sources indicated by the number) with those from ERA-Interim (as the reference).

positive and negative values. The latitude of the maximum is determined by a weighted arithmetic-mean method (Davis and Rosenlof 2012) as follows:

$$
\phi_{\max }=\frac{\sum_{i=20^{\circ}}^{50^{\circ}} \phi_{i} \cos \phi_{i} q_{i}}{\sum_{i=20^{\circ}}^{50^{\circ}} \cos \phi_{i} q_{i}},
$$

where $\phi_{i}$ denotes the latitude, $q_{i}$ denotes the diagnostic variable (here, it refers to the zonal-mean meridional TP gradient and $U$ ), and $\phi_{\max }$ is the "mean" latitude weighted by the product of the area $\cos \phi_{i}$ and diagnostic variable $q_{i}$. The integral range depends on the distribution of the diagnostic variable (Fig. 1 ): $20^{\circ}-50^{\circ} \mathrm{N} / \mathrm{S}$ for the meridional TP gradient; $20^{\circ}-45^{\circ} \mathrm{N} / \mathrm{S}$ for the $200-\mathrm{hPa}$ $U$; and $30^{\circ}-60^{\circ} \mathrm{N}$ and $40^{\circ}-60^{\circ} \mathrm{S}$ for the northern and southern $850-\mathrm{hPa} U$, respectively. The defined meanmaximum latitude $\phi_{\max }$ is similar to the latitude determined by the extreme maximum of grid points, but it is more sensitive to subtle distribution changes near the peak and more robust to the potential influence of noise.

\section{Model evaluation}

The ability of the models to reproduce the spatial patterns of the annual-mean zonal-mean MMS, TP, $U$, and $P-E$ within the range of $60^{\circ} \mathrm{S}-60^{\circ} \mathrm{N}$ is evaluated. The similarity between simulated and observed patterns

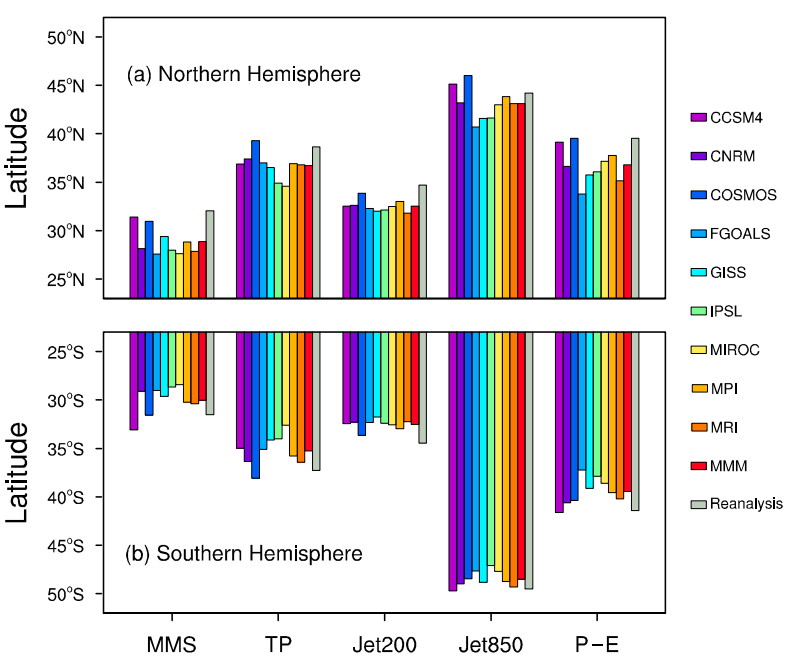

FIG. 3. Locations of each metric derived from the individual model preindustrial experiments, the MMM, and the arithmetic mean of all the reanalyses used in this study.

is quantified in terms of their correlation, their centered root-mean-square (RMS) difference, and their standard deviations. All of these statistics are summarized in a Taylor diagram (Taylor 2001) as shown in Fig. 2. Note that the RMS difference and two standard deviations of each variable are normalized by the standard deviation of the corresponding observed fields before appearing on the same graph. The observed fields here are derived from ERA-Interim, and their statistical relationships with other reanalyses are also displayed in the Taylor diagram.

Generally, the simulated patterns are located near the reference point, suggesting that the PMIP3/CMIP5 models are able to capture the large-scale features of the diagnostic variables. The correlations of all patterns from other reanalyses and models with those from ERA-Interim are greater than 0.96 and 0.78 , respectively, both of which are statistically significant at the $99.9 \%$ confidence level. Relative to all the reanalyses used in this study, models tend to exaggerate the variation amplitude of $U$ and to underestimate that of TP. But for MMS and $P-E$, the conclusions are reanalysis dependent. Nevertheless, the normalized standard deviations of the simulated patterns are within the acceptable range $(1 \pm 0.5)$, with the exception of the TP simulated by FGOALS. Since the TP error of FGOALS is mainly due to the overestimated tropopause height at middle and high latitudes (not shown), while changes in the low-latitude atmospheric circulation are focused on in this study, we retain all nine models in the subsequent analysis.

Figure 3 shows the locations of the metrics used to indicate the tropical edge changes. In this plot, 
(a) $\mathrm{NH}$ tropical edge poleward shift $\left({ }^{\circ}\right.$ lat $)$

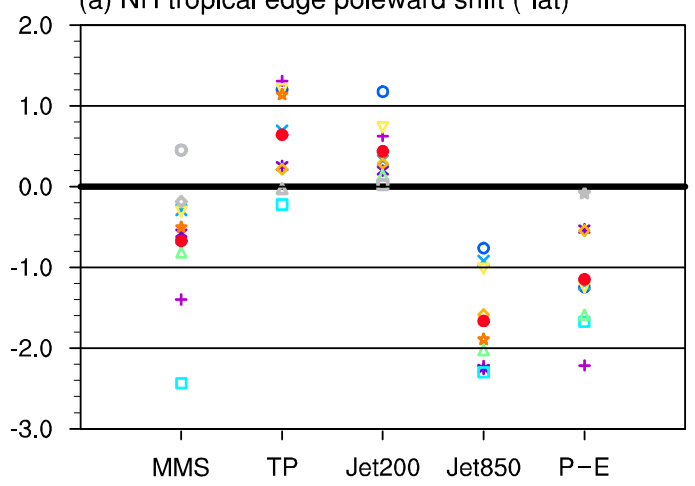

(b) SH tropical edge poleward shift ( ${ }^{\circ}$ lat)

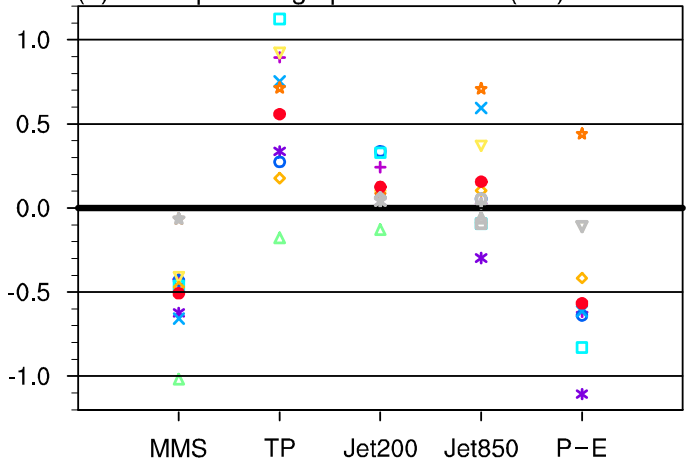

(c) Total tropical belt width change ('lat)

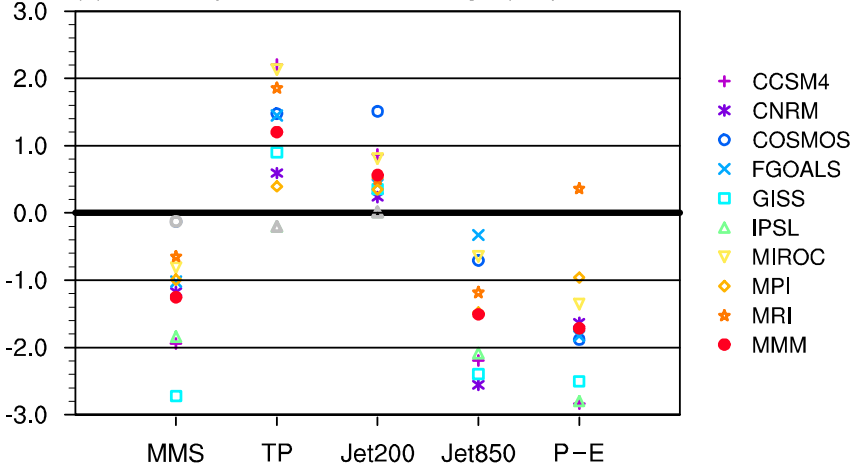

FIG. 4. Poleward shifts of the LGM (a) NH and (b) SH tropical edges, and (c) changes in the total tropical belt width compared to the preindustrial period, as indicated by each metric. For individual models, gray indicates that the model failed to pass the statistical significance test at the $95 \%$ confidence level.

different colors represent different data sources, and results determined by the same metric are grouped together. Among all these indicators, the MMS-based edges are closest to the equator, with the averaged latitude around $30^{\circ}$ in each hemisphere. In contrast, the northern and southern peaks of the $850-\mathrm{hPa}$ jet are located north of $40^{\circ} \mathrm{N}$ and south of $45^{\circ} \mathrm{S}$, respectively. As mentioned above, the 850-hPa jet does not represent the exact location of the tropical edge, but it is an indicator of tropical edge shift. For each metric, the latitudes at both hemispheres are systematically biased equatorward in the PMIP3/CMIP5 models relative to the reanalyses. To minimize the influence of an inconsistent period on the model-reanalysis discrepancy, we also compare the results from the historical simulations (1979-2005) to those from the reanalyses (not shown). It is found that the equatorward bias still exists in the historical simulations, and the magnitude of such bias is comparable to that from the preindustrial simulations.

\section{Shifts of the LGM tropical edges}

Figures $4 \mathrm{a}$ and $4 \mathrm{~b}$ show the difference in the northern and southern tropical edges, respectively, between the
LGM and preindustrial experiments, where positive values denote poleward shifts. For each metric, the results of most models are statistically significant at the 95\% confidence level. In contrast to the consistent tropical expansion measured by a variety of observations since 1979, the moving direction of the LGM tropical edges principally depends on the choice of metric. Note that the moving direction could also be opposite in different models, but the majority of them (at least six out of nine) are in agreement with each other. In the NH, the LGM tropical edges determined by MMS and $P-E$, along with the metric Jet850, yield an equatorward movement, while those determined by TP and Jet200 shift poleward. Except for Jet850, the moving direction indicated by other metrics in the $\mathrm{SH}$ is symmetrical to those in the NH. The results of the total tropical belt width (the sum of changes at both hemispheres) are shown in Fig. 4c. We find that the LGM tropics become narrower, as suggested by the metrics defined from the atmospheric properties in the lower and middle troposphere (MMS, Jet850, and $P-E$ ), and the tropics expand, as suggested by the metrics derived from the tropospheric upper level (TP and Jet200). These changes can also be seen in the spatial distribution 

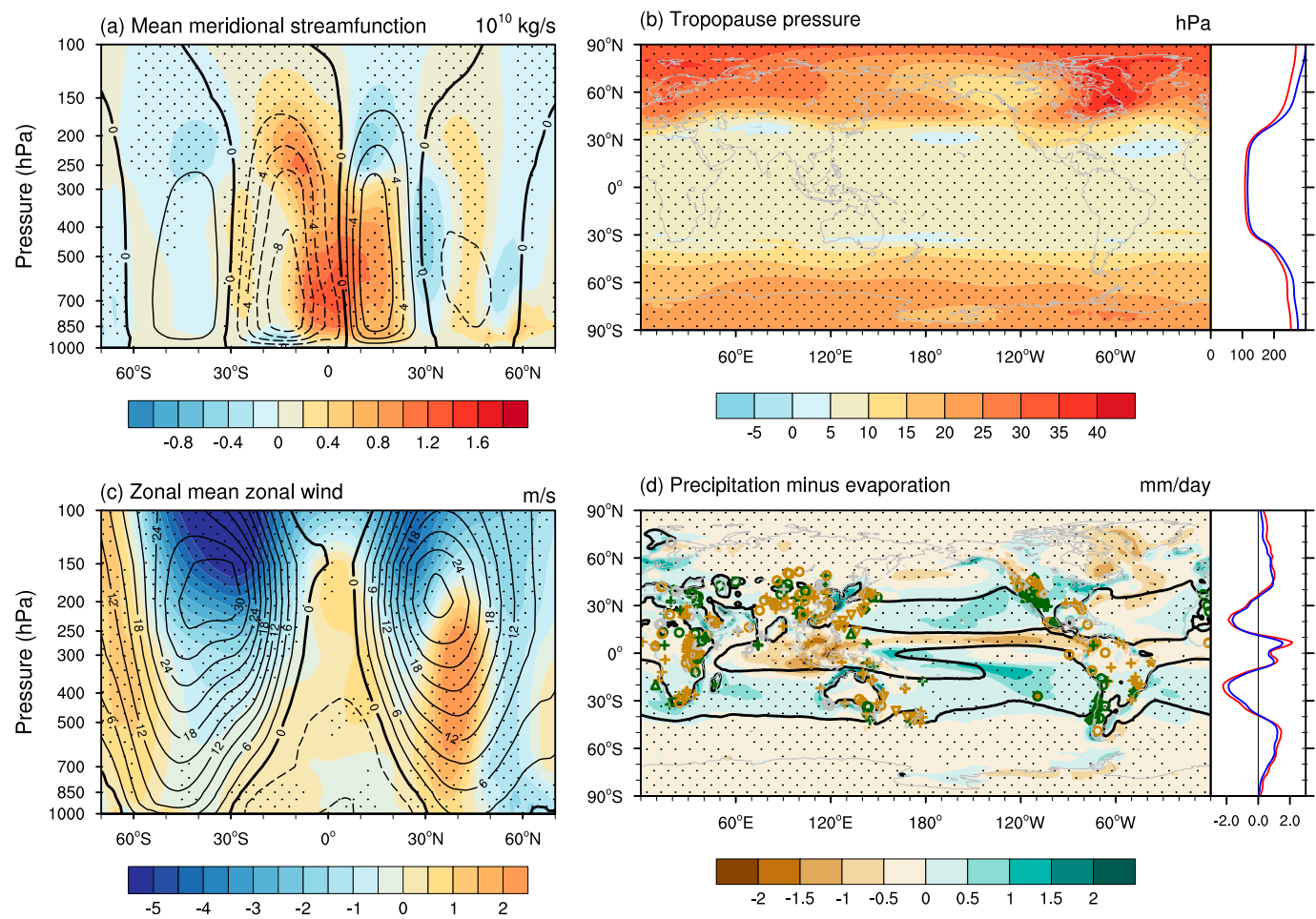

FIG. 5. The MMM LGM-minus-preindustrial anomalies (color shading) of (a) MMS (black contours denote preindustrial values), (b) TP, (c) zonal-mean $U$ (black contours denote preindustrial values), and (d) $P-E$ (black contours denote preindustrial zero isopleths). The dotted areas indicate that at least seven out of nine models agree with the sign of change. The zonal-mean TP and $P-E$ are attached at the right sides of (b) and (d), respectively, showing the preindustrial (red) and the LGM (blue). In (d), the reconstructed changes in moisture from pollen assemblages (cross), lake status (circle), glacier (square), mineral sediments (triangle), fauna (inverted triangle), speleothems (diamond), and aeolian materials (star) are classified into wetter (green), no change (gray), and drier (yellow).

of the related metrics (Fig. 5) and are robust to the various choices of models with at least eight out of nine model agreements (Fig. 4c).

Quantitatively, the shift magnitudes derived from different models feature considerable discrepancy. The differences between the maximum and minimum shifts in the $\mathrm{NH}$ are greater than $1^{\circ}$ for each metric, especially for MMS and $P-E$, the maximum model differences of which are greater than $2^{\circ}$. In the $\mathrm{SH}$, the spreads in models are systematically reduced, as the absolute shift magnitudes are smaller than their northern counterparts. The maximum model differences of the total tropical belt width among metrics range from $1.5^{\circ}$ (Jet200) to $3.2^{\circ}(P-E)$. We use the arithmetic mean to represent the central tendency of the multiple model results, symbolized by the red dots in Fig. 4. In absolute terms, Jet200 indicates the smallest width change of $\sim 0.6^{\circ}$ for the multimodel mean (MMM), while the magnitude indicated by other metrics ranges from $1.2^{\circ}$ to $1.7^{\circ}$. The total width changes predominantly reflect contributions from the $\mathrm{NH}$, especially for $P-E$ and the jet-based metrics. The MMM northern tropical edge shifts indicated by the above metrics are 1-2 times larger than those in the SH. According to the reconstruction (Abe-Ouchi et al. 2015), the hemispherical-scale ice sheets are characterized by asymmetrical growth during the LGM, with more ice accumulations in the NH. We speculate that the incongruous shifts of the LGM northern and southern tropical edges are possibly due to the difference in the boundary conditions between the hemispheres.

The LGM tropical mean surface temperature equatorward of $30^{\circ}$ relative to the preindustrial is $-2.8 \mathrm{~K}$ for the MMM (not shown). The absolute total tropical belt width varies with the tropical temperature at a rate of $0.2-0.6^{\circ} \mathrm{K}^{-1}$ among metrics. This range is smaller than the $\sim 0.7^{\circ} \mathrm{K}^{-1}$ measured by the Hadley cell in the CMIP5 simulations spanning from the LGM via the mid-Holocene and historical to global warming scenarios (D'Agostino et al. 2017) and the $\sim 0.9^{\circ} \mathrm{K}^{-1}$ only in the CMIP5 historical simulations for the period 1979-2005. The latter rate was calculated from the Hadley cell widening of $\sim 0.17^{\circ} \mathrm{decade}^{-1}$ as suggested by $\mathrm{Hu}$ et al. (2013), along with the estimated 
(a) Air temperature

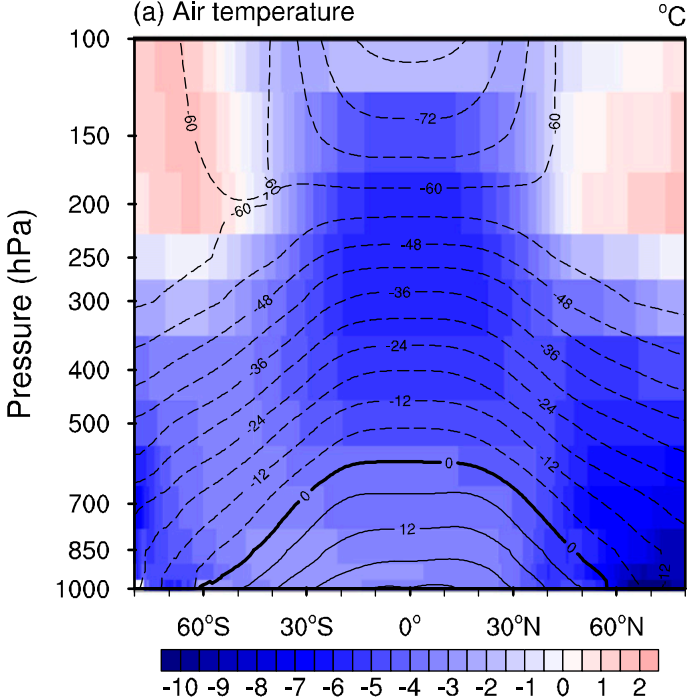

(c) Vertical temperature gradient

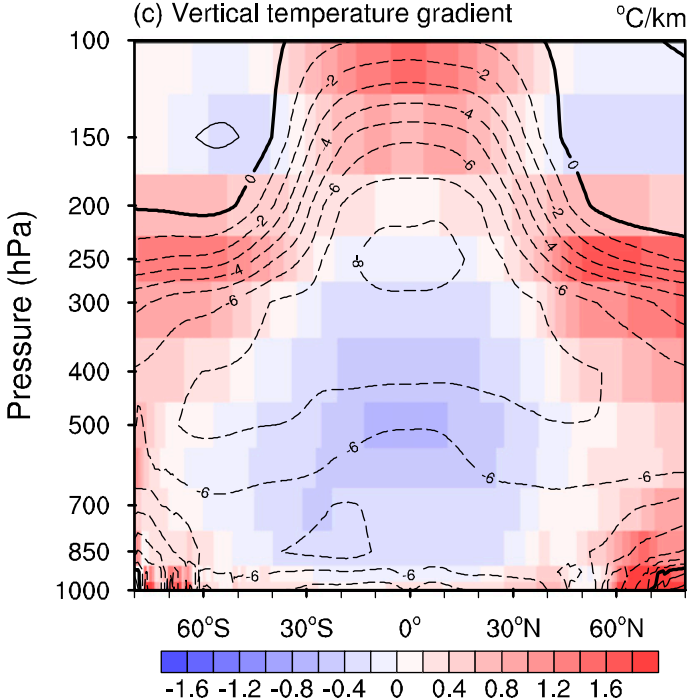

${ }^{\circ} \mathrm{C}$

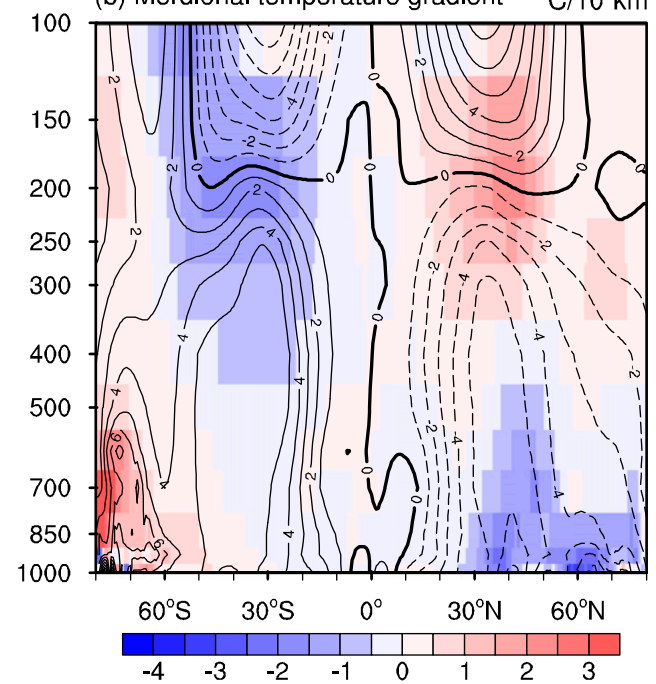

(d) Maximum Eady growth rate

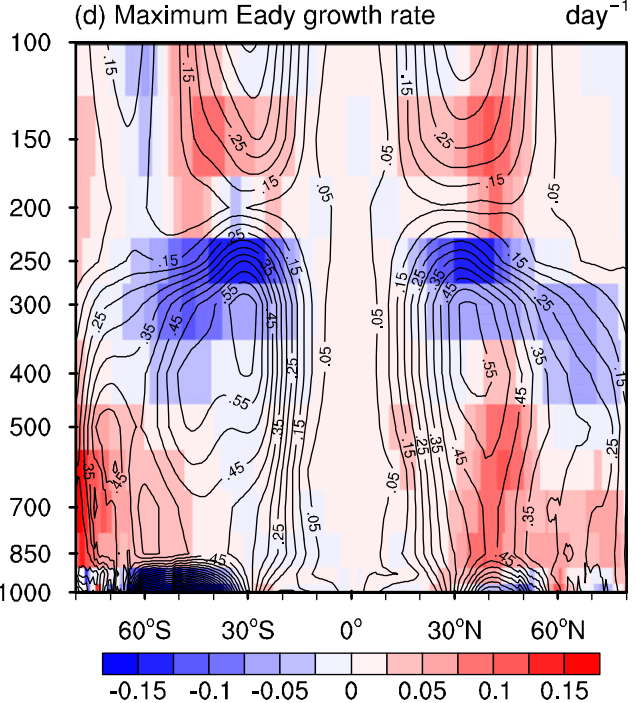

FIG. 6. The MMM preindustrial distribution (black contours) and LGM-minus-preindustrial anomalies (color shading) of the (a) zonal-mean air temperature, (b) MTG (positive northward), (c) VTG (positive upward), and (d) MEGR.

contemporaneous tropical surface temperature anomalies of $\sim 0.19 \mathrm{~K} \mathrm{decade}^{-1}$. Here the tropical rather than the global mean surface temperature is used to minimize the influence of polar amplification, consistent with previous studies (D'Agostino et al. 2017). The discrepancy in rate may be attributed to the metric selection, and also the distinct mechanisms responsible for the tropical belt width changes during different periods of concern.

\section{Relationship to thermal redistribution}

The expanded ice sheets and lowered GHG concentrations during the LGM congruously point to a much colder troposphere relative to the preindustrial period. The spatial distribution of such cooling featuring considerable heterogeneity, along with the GHG-induced stratospheric warming, contributes to subsequent variations in the meridional temperature gradient (MTG), static stability, and baroclinicity (Fig. 6). The interaction between thermal structure and atmospheric circulation is critical to the behavior of the tropical belt during the LGM. Here, we analyze the possible mechanisms responsible for the tropical edge shifts indicated by different metrics through their relationships to the glacial thermal redistribution. For the zonal-mean field, the changes in the thermal-related variables over a selected section are divided into two categories: the area-weighted 
mean value anomalies $\Delta \sigma_{\text {mean }}$ and the changes in the zonal distribution, indicated by the shifts of the meanmaximum latitude $\Delta \phi_{\max }$. Note that the vertical average is calculated when considering the integral changes of variables at multiple pressure levels.

\section{a. Hadley cell}

In theories assuming angular momentum and energy conservation (Held and Hou 1980), the poleward extent of the axisymmetric Hadley cell is controlled by the equator-to-pole temperature gradient and tropical tropopause height. However, this idealized model neglects the role of baroclinic eddies, which are widely observed in the real atmosphere, especially near the subtropical Hadley cell edges. Therefore, another view argues that the Hadley cell extent is limited by the baroclinic instability. The edge of the Hadley cell is where the baroclinic eddy activity is strong enough that the eddy momentum flux acts to break the angular momentum conservation (Salmon et al. 2001; Walker and Schneider 2006; Frierson et al. 2007; Hu et al. 2018). In this study, baroclinic instability is quantified by the maximum Eady growth rate (MEGR), which is equivalent to the ratio of the vertical wind shear to static stability (Vallis 2006). Since the vertical wind shear and static stability are determined by the meridional and vertical temperature gradients, respectively, changes in the baroclinicity are also regarded as responses to the thermal redistribution.

As shown in Fig. 6, the NH subtropical baroclinicity apparently increases in the middle and lower troposphere under the joint effect of increased meridional temperature gradient and reduced static stability, whereas in the SH the subtropical baroclinicity is slightly increased and even reduced over some regions as a result of the accordant reduction in both the meridional temperature gradient and static stability. For individual models, we select a cross section $\left(20^{\circ}-30^{\circ} \mathrm{N} / \mathrm{S}\right.$ and 500 $850 \mathrm{hPa}$ ) near the Hadley cell edge and then quantify the regional baroclinicity changes of each model. The results are illustrated in Figs. 7 and 8, along with their relationships to the shifts of the MMS-based tropical edge. The aforementioned $\mathrm{NH}$ baroclinicity enhancement is robust in six out of nine models (Fig. 7a), and the enhancement tends to be stronger at the lower latitudes, which is demonstrated as the equatorward shift of the mean-maximum latitude of baroclinicity (Fig. 7b). Although the linear relationship between the shift of tropical edge and the change of baroclinicity is statistically significant, it should be noted that the high correlation depends highly on GISS. In the SH, the MMM results show little changes in the area-weighted mean baroclinicity but an equatorward shift of the meanmaximum latitude of baroclinicity (Figs. $8 \mathrm{a}$ and $8 \mathrm{~b}$ ). A high correlation is also found between the shift of the mean-maximum latitude of baroclinicity and the $\mathrm{SH}$ tropical edge among models (correlation of 0.72 ). The different responses of northern and southern baroclinicity contribute to an identical consequence; that is, the critical baroclinic instability modulating the boundary of the Hadley cell is located more equatorward during the LGM and in turn is associated with the tropical contraction measured by MMS.

\section{b. Tropopause pressure}

According to the World Meteorological Organization (WMO 1957), here the tropopause is identified as the lowest pressure level where the lapse rate decreases to $2^{\circ} \mathrm{C} \mathrm{km}^{-1}$ or less, and the average lapse rate between this level and all higher levels within $2 \mathrm{~km}$ does not exceed $2^{\circ} \mathrm{C} \mathrm{km}^{-1}$, using the algorithm of Reichler et al. (2003). Therefore, shifts of the TP-based tropical edge can be further linked to changes in the meridional and vertical temperature distributions through the definition of this metric. During the LGM, declined GHG concentrations coupled with the background lapse rate result in the large-scale tropospheric cooling and stratospheric warming (Fig. 6a). The LGM TP is systematically increased in response to the decreased lapse rate near the tropopause (Fig. 6c), indicating the drop in tropopause height (Fig. 5b). In particular, the tropospheric cooling is reinforced by the mass accumulation of ice sheets at the high latitudes, where the lapse-rate reduction and TP increase are largest. Additionally, the latent heat release is speculated to weaken as result of the lack of water vapor from the cold surface ocean, which is associated with the enhanced tropical upper-level cooling and the subsequent reduction in tropopause height. The smallest changes in TP are along latitude $\sim 30^{\circ} \mathrm{N} / \mathrm{S}$, where the tropopause height is even higher over some specific regions (Fig. 5b). The latitudinally uneven changes of TP indicate that more extratropical regions at the tropical edge are characterized by tropical high-tropopause properties during the LGM, contributing to the poleward shift of the maximum in the meridional TP gradient (Fig. 4).

The magnitude of TP-based tropical edge shifts is sensitive to the variations in the subtropical TP. Based on the nine model results, approximately $75 \%(56 \%)$ of the spread in the poleward shift of the northern (southern) TP-based tropical edges can be explained by a linear relation to the TP changes in the subtropics $\left(25^{\circ}-40^{\circ} \mathrm{N} / \mathrm{S}\right)$. We further calculate the area-weighted mean changes of the vertical temperature gradient (VTG) near the subtropical tropopause and find they are highly correlated with the shifts of the TP-based tropical edge at both hemispheres (Figs. 7c and 8c). It 


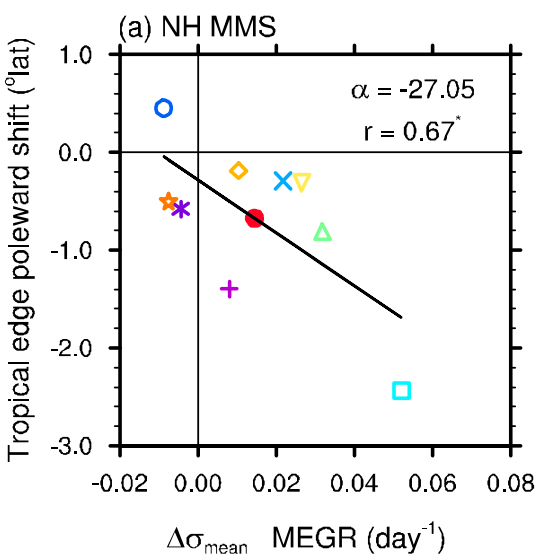

$<20^{\circ} \mathrm{N}-30^{\circ} \mathrm{N}><500 \mathrm{hPa}-850 \mathrm{hPa}>$ (b) $\mathrm{NH}$ MMS

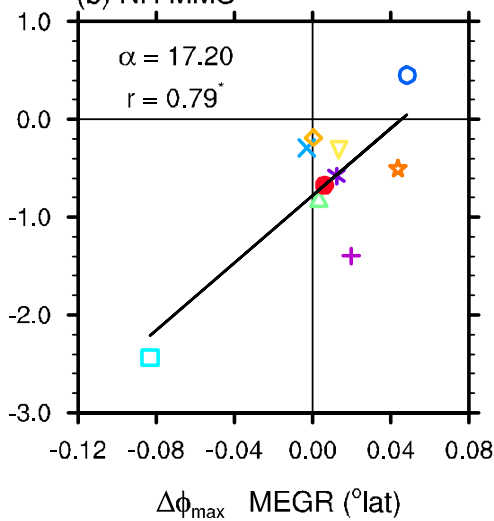

$<20^{\circ} \mathrm{N}-30^{\circ} \mathrm{N}><500 \mathrm{hPa}-850 \mathrm{hPa}>$ (c) NH TP

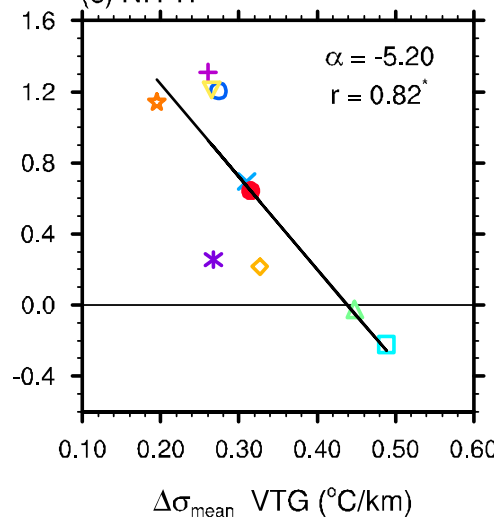

$<25^{\circ} \mathrm{N}-40^{\circ} \mathrm{N}><100 \mathrm{hPa}-300 \mathrm{hPa}>$

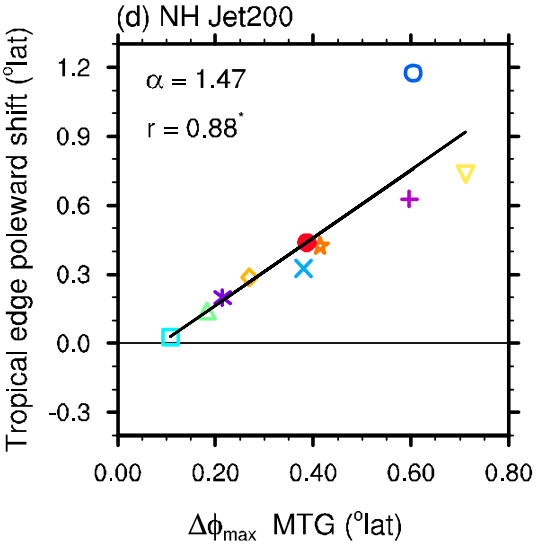

$<20^{\circ} \mathrm{N}-45^{\circ} \mathrm{N}><200 \mathrm{hPa}-850 \mathrm{hPa}>$

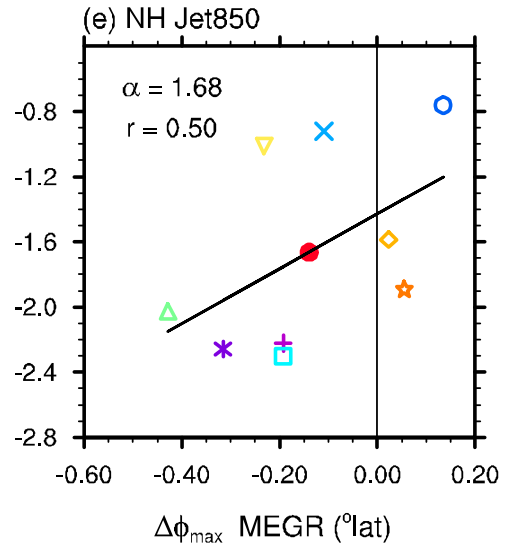

$<30^{\circ} \mathrm{N}-60^{\circ} \mathrm{N}><700 \mathrm{hPa}-925 \mathrm{hPa}>$

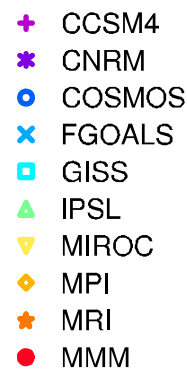

FIG. 7. Relationships between the poleward shifts of the metrics and changes in the thermal distribution (LGM minus preindustrial) in the NH. The variable $\Delta \sigma_{\text {mean }}$ denotes the area-weighted mean change and $\Delta \phi_{\text {max }}$ denotes the poleward shift of the mean-maximum latitude of the MEGR, VTG, or MTG over the zonal-mean cross section, as indicated in the angle brackets. Regression coefficients $\alpha$ and correlation coefficients $r$ are labeled inside each panel. The statistically significant correlations at the $95 \%$ confidence level are indicated by asterisks.

suggests that the TP-based tropical expansion is more obvious in models simulating tiny changes in the vertical temperature gradient in the subtropical upper troposphere.

\section{c. Jets}

Figure 5c shows the MMM zonal-mean zonal wind anomalies (LGM minus preindustrial). In the $\mathrm{NH}$, the 200-hPa zonal wind is robustly weakened to the south of the preindustrial wind speed maximum and strengthened at its northern side, indicating the poleward shift of the $200-\mathrm{hPa}$ jet stream mentioned above. For the $\mathrm{SH}$, the wind speed is extensively reduced at both sides of the jet stream but less so at its southern side. The $\mathrm{SH}$ 200-hPa jet stream also shifts poleward in response to the asymmetrical changes in the zonal wind, but it is smaller in magnitude compared to that in the NH (Figs. $4 \mathrm{a}$ and 4b). These zonal wind anomalies are associated with changes in the meridional temperature gradient through the thermal wind relationship. As shown in Fig. 6b, the meridional temperature gradient is remarkably reduced near the subtropical tropopause as a result of the GHGinduced cooler troposphere and warmer stratosphere, which is consistent with the negative zonal wind anomalies. In contrast, the positive zonal wind anomalies north of the NH 200-hPa jet stream (Fig. 5c) are connected with the notably increased meridional temperature gradient in the lower troposphere as a result of the extensive expansion of ice sheets. This implies that the upper-level zonal wind is not simply related to the thermal distribution at its adjacent levels but influenced by the combination of changes in the vertical direction. Taking the meridional temperature gradient from the 


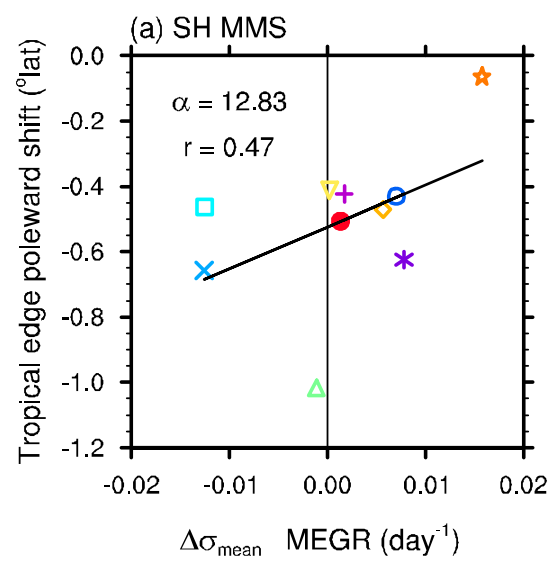

$<20^{\circ} \mathrm{S}-30^{\circ} \mathrm{S}><500 \mathrm{hPa}-850 \mathrm{hPa}>$

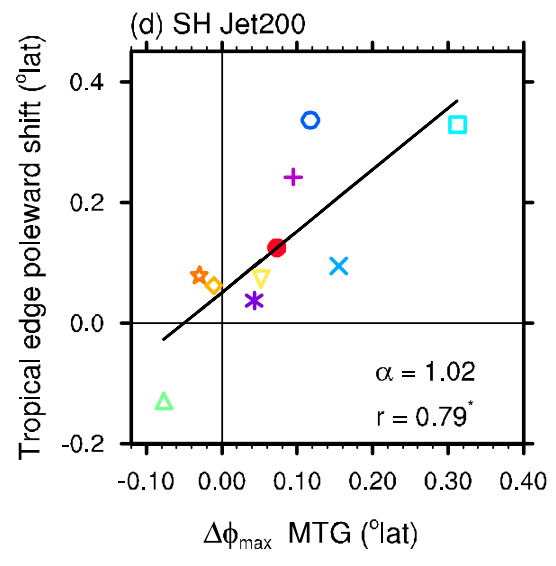

$<20^{\circ} \mathrm{S}-45^{\circ} \mathrm{S}><200 \mathrm{hPa}-850 \mathrm{hPa}>$
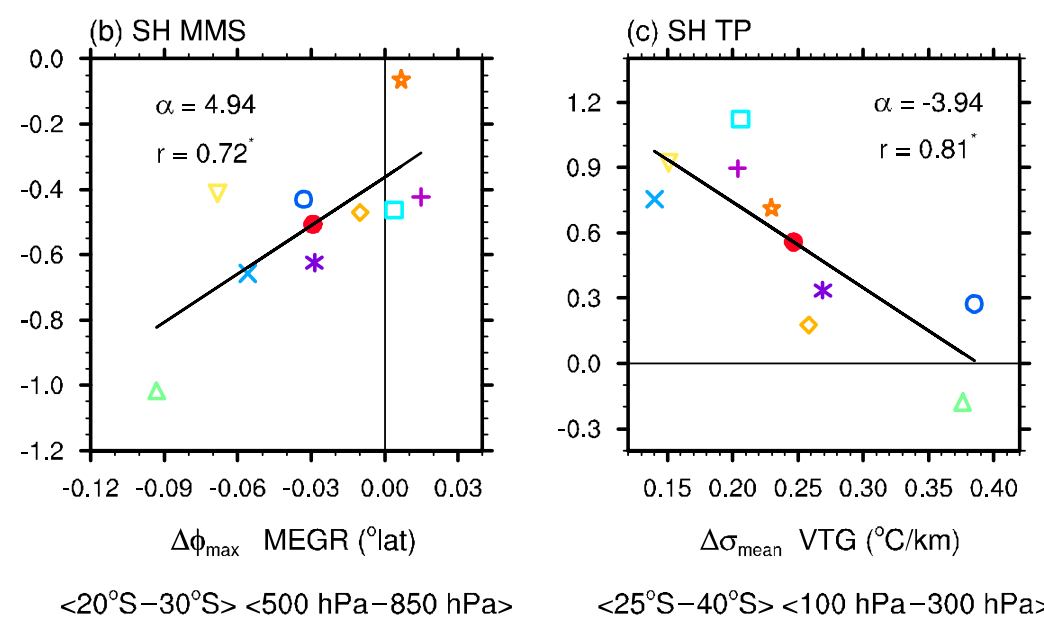

$<25^{\circ} \mathrm{S}-40^{\circ} \mathrm{S}><100 \mathrm{hPa}-300 \mathrm{hPa}>$
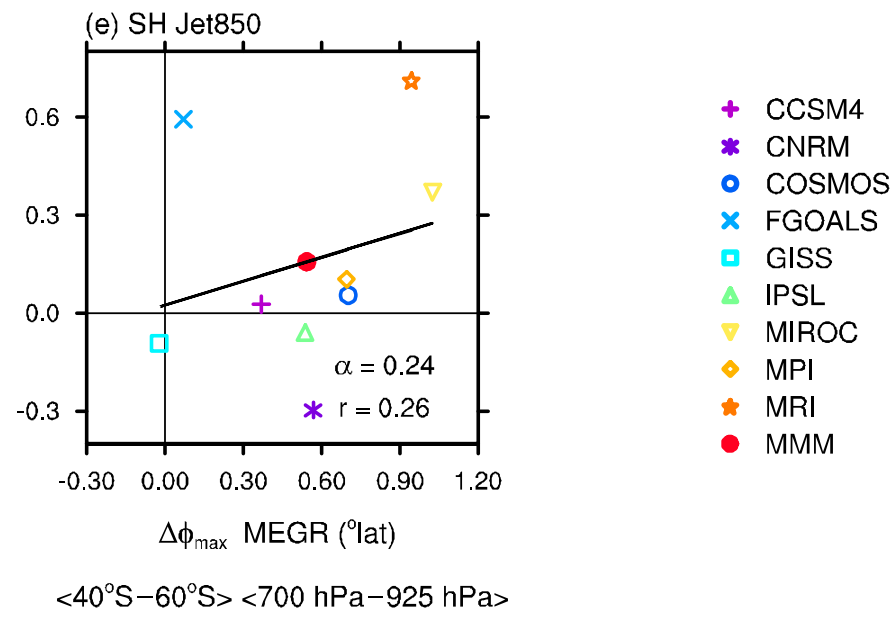

FIG. 8. As in Fig. 7, but for the SH.

lower troposphere up to the $200 \mathrm{hPa}$ as a whole, the shift of the mean-maximum latitude of this integral is strongly correlated with the shift of the $200-\mathrm{hPa}$ jet stream (Figs. $7 \mathrm{~d}$ and $8 \mathrm{~d}$; correlations of 0.88 and 0.79 for $\mathrm{NH}$ and $\mathrm{SH}$, respectively).

The $850-\mathrm{hPa}$ zonal wind maximum has been widely used to represent the eddy-driven jet, which is maintained by the eddy momentum flux convergence in regions of enhanced baroclinicity. Therefore, the behavior of the $850-\mathrm{hPa}$ jet stream is expected to be connected with changes in baroclinicity. As illustrated in Fig. 6d, the LGM low-level baroclinicity is substantially increased at both hemispheres but with different spatial features. In the $\mathrm{NH}$, the stronger enhancement of baroclinicity exists south of $45^{\circ} \mathrm{N}$, giving rise to the equatorward movement of the maximum. In contrast, the $\mathrm{SH}$ baroclinic zone is characterized by a poleward shift, as positive anomalies are concentrated at higher latitudes. These contrasting shifts of maximum baroclinicity are consistent with the opposite behavior of the northern and southern $850-\mathrm{hPa}$ jet streams. In both hemispheres, there are six out of nine models showing the consistency in move directions of the maximum baroclinic zone and the $850-\mathrm{hPa}$ jet stream. However, the relationship between these two quantities is nonlinear, given their feedback through the generation, propagation, and breaking of baroclinic eddies.

\section{d. Precipitation minus evaporation}

As a manifestation of the local water cycle, $P-E$ is more than the metric but is also one of the surface impacts of variations in the tropical edge. The overall characteristic of $P-E$ response to the LGM boundary conditions is a counteraction of the climatological background pattern, with the wet getting drier and the dry getting wetter (Fig. 5d). Except in the North Atlantic, $P-E$ is increased near the poleward boundary of the subtropical dry zones, which is reflected in the equatorward shift of the zero isopleths (Fig. 4). Using the reconstructed moisture conditions as a benchmark, 
(a) $\mathrm{NH}$

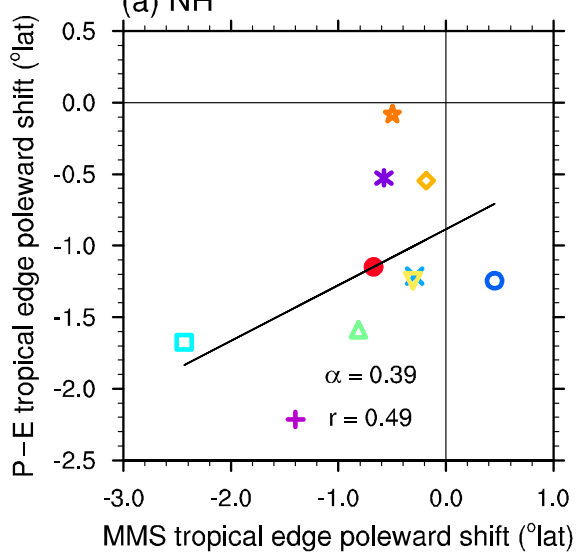

(b) $\mathrm{SH}$

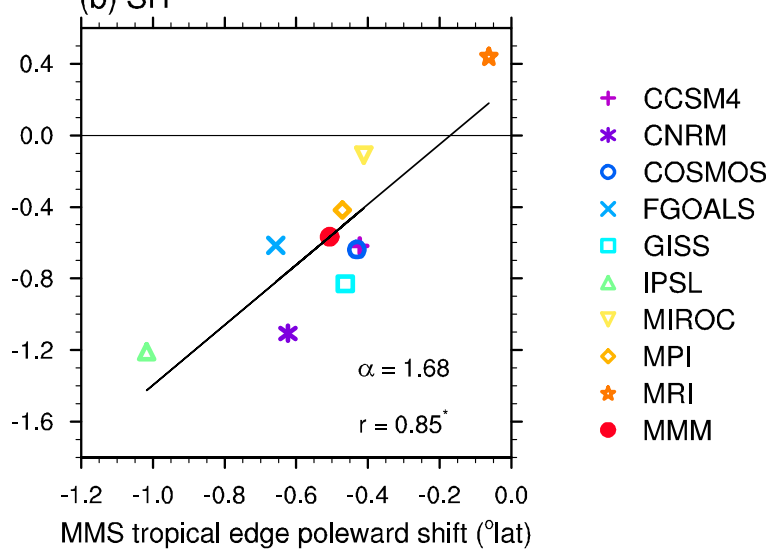

FIG. 9. Relationships between the poleward shifts of the tropical edge measured by $P-E$ and those measured by MMS in (a) the NH and (b) the SH.

the simulated $P-E$ patterns agree qualitatively with available terrestrial records in the $\mathrm{NH}$, while in the $\mathrm{SH}$ the records themselves show uncertainty (see the appendix). By comparing the tropical edges determined by MMS and $P-E$, we find a strong correlation between these two metrics in the SH (Fig. 9). However, such a linear relationship is not significant in the $\mathrm{NH}$, probably because of the inhomogeneous changes in $P-E$ along the parallel. As far as the tendency is concerned, the results of both hemispheres indicate that the subtropical dry zones contract during the LGM in response to the equatorward shift of the Hadley cell's descending branch. Given the role of baroclinicity in modulating the Hadley cell extent, we consider the shifts of the tropical edge determined by $P-E$ to be indirectly related to changes in the thermal distribution.

\section{Summary and discussion}

Based on the PMIP3/CMIP5 simulations, we examined the LGM tropical belt width changes relative to the preindustrial period, and we found that the tendency of such changes varies with metrics. In the $\mathrm{NH}$, the tropical belt tends to contract as measured by the Hadley cell extent (MMS), the eddy-driven jet (Jet850), and the marginal boundary of the subtropical dry zone $(P-E)$; in contrast, the tropopause-related metric (TP) and the subtropical jet (Jet200) indicate a poleward shift of the tropical edge. Except for the eddy-driven jet, the moving direction of other metrics in the $\mathrm{SH}$ are symmetrical to their northern counterparts. These qualitative results are robust, with at least six out of nine models in agreement, although the magnitude of these changes features substantial model discrepancy. The multimodelmean total width change during the LGM is smallest in
Jet200 $\left(\sim 0.6^{\circ}\right)$ and largest in $P-E\left(\sim 1.7^{\circ}\right)$ in absolute terms. Such magnitudes are smaller than those in accompany with the observed and projected global warming, considering the contemporaneous changes in the tropical surface temperature (Hu et al. 2013; D'Agostino et al. 2017).

The five independent metrics can be alternatively classified according to their height in the troposphere. The two metrics (TP and Jet200) that indicate tropical expansion are located at the upper levels, while other metrics (MMS, Jet200, and $P-E$ ) that point to narrower tropics are located at the middle and lower levels. The contrasting behaviors of the upper- and lower-level metrics during the LGM are consistent with the previous studies on the covariability among different metrics. Analyzing outputs from large-ensemble preindustrial simulations along with the atmospheric reanalyses, Solomon et al. (2016) found that at least in the SH, the width of Hadley cell is strongly correlated with $P-E$ and the eddy-driven jet on interannual and decadal time scales, but it is uncorrelated with the tropopause gradient and the subtropical jet. Such a relationship has been reaffirmed by Waugh et al. (2018) for both hemispheres, using the CMIP5 preindustrial simulations. Both of them also found the lower- and midlevel metrics exhibit significant poleward shifts in response to the increased GHG forcing, while the upper-level metrics show weak or opposite responses.

The aforementioned discrepancies are attributable to the underlying mechanisms responsible for the metric changes. The LGM atmospheric thermal structure in response to the low-level GHG concentrations features large-scale tropospheric cooling and stratospheric warming. The reduced latent heat release and expanded ice sheets give rise to the enhanced cooling at the 
tropical upper levels and the high-latitude lower troposphere. Such homogeneity in thermal structure interacts with the atmospheric circulation and subsequently builds its relationship with the tropical belt width. Through the definition of tropopause and the thermal wind relationship, the TP-based tropical edge and the subtropical jet are sensitive to the vertical and meridional temperature gradients in the subtropics. There is a significant correlation ( 0.83 ) between TP and Jet200 in the $\mathrm{NH}$ but not in the $\mathrm{SH}$ (correlation of 0.57). As suggested by Waugh et al. (2018), these two metrics may measure similar aspects of the circulation, but they are uncorrelated with the Hadley cell width changes. The connection between the Hadley cell and the eddy-driven jet is established through anomalous baroclinic eddy activities. The poleward extent of the Hadley cell is limited by the latitude where baroclinic instability exceeds a threshold, whereas the eddy-driven jet shifts with the latitude of maximum baroclinicity. Our argument on the baroclinicity is consistent with the discussion given by Davis and Birner (2017), in which they suggested the Hadley cell and the eddy-driven jet are both physically linked to the distribution of eddy momentum fluxes. During the LGM, the NH low-level baroclinicity is remarkably increased south of $45^{\circ} \mathrm{N}$ and the maximum baroclinic zone shifts equatorward, which is related to the equatorward shift of MMS and Jet850. In the $\mathrm{SH}$, there is a slight increase in the subtropical low-level baroclinicity, while the polar baroclinicity is substantially enhanced, accordingly leading to the equatorward shift of MMS and the poleward shift of Jet850. Given that the MMS and Jet850 are closely associated with the distribution of $P-E$ and the behavior of storm tracks (Nakamura and Shimpo 2004; Laîné et al.2009), this low-level baroclinicity could be used as a proxy to indicate the surface climate impact of tropical belt width changes.

Although we have used all available models, this study is still far from sufficient to establish a solid statistical relationship between the tropical edge shifts and changes in the thermal distribution. The responses of tropical belt changes to a wide range of climate regimes in different model realizations are expected to further corroborate our results. It should also be noted that all of the present results are derived from the zonal-mean field, which captures the dominant characteristics of large-scale patterns but is probably inconsistent with local conditions. For instance, the zonal-mean Hadley cell is shown to be well described by three regionally distinct cells along the eastern edges of the major ocean basins with opposite circulations elsewhere (Karnauskas and Ummenhofer 2014). Wang et al. (2018) suggested the equatorward shift of the LGM low-level jet stream in the NH is manifested in the North Pacific and Eurasia but inconspicuous in the North Atlantic. The zonally asymmetric distribution of $P-E$, as shown in Fig. 5d, is another line of evidence. Understanding the distinct regional reflection of global tropical belt changes is probably the next step in better evaluating its influence on human society.

Acknowledgments. We sincerely thank the three anonymous reviewers for their insightful comments and suggestions for improving this manuscript. We also acknowledge the climate modeling groups participating in the PMIP3/CMIP5 for producing and sharing their model outputs. This work was supported by the Strategic Priority Research Program of the Chinese Academy of Sciences (XDA20070103) and by the National Natural Science Foundation of China (41625018, 41421004, and 41430962).

\section{APPENDIX}

\section{Model-Data Comparison}

In this appendix we examine the relationship of the simulated tropical belt width changes to those inferred from paleoenvironmental reconstructions, based on a synthesis of the observed moisture conditions during the LGM (Farrera et al. 1999; Kohfeld et al. 2013; Jiang et al. 2015; Wang et al. 2018). The moisture data shown in Fig. 5d were collected from 419 sites at low and middle latitudes, including evidence from pollen assemblages, lake-level status, glaciers, mineral sediments, faunal assemblages, and speleothems. In western North America and South America, sites at the poleward edge of the subtropical dry zone all experienced wetter conditions, regardless of the data sources. A similar phenomenon can also be seen to the northwest of the Mediterranean. These spatially homogenous moisture changes agree well with the simulated $P-E$ patterns, which are attributed to the equatorward shift of westerly winds (Oster et al. 2015; Wang et al. 2018). In contrast, the majority of sites over East Asia and eastern North Africa experienced drier conditions, as manifestations of the southward retreat of the monsoon area (Jiang et al. 2015). Yan and Petit-Maire (1994) also suggested that the Afro-Asian arid-semiarid transitional zone shifted southward by several hundred kilometers during the LGM, which is supported by a great number of geological and other proxy records. At the large scale, the simulated $P-E$ anomalies agree qualitatively with the available terrestrial reconstructions in the $\mathrm{NH}$. In the $\mathrm{SH}$, except for western South America, the paleodata themselves show contradictory changes in terrestrial 
moisture conditions (Fig. 5d), and such uncertainty makes it difficult to perform a transparent model-data comparison. Nevertheless, the reconstructed sea surface temperature from diatom, radiolarian, and planktonic foraminiferal assemblages argue for the northward movement of the LGM Subtropical Front over the southern Atlantic and Indian Oceans (Gersonde et al. 2003). Modern evidence from observations suggests that major storm tracks are organized along or just downstream of the oceanic frontal zones (Nakamura et al. 2004). Thus, the shifts in the frontal position indirectly support the simulated changes in hydrological cycles.

\section{REFERENCES}

Abe-Ouchi, A., and Coauthors, 2015: Ice-sheet configuration in the CMIP5/PMIP3 Last Glacial Maximum experiments. Geosci. Model Dev., 8, 3621-3637, https://doi.org/10.5194/gmd-8-3621-2015.

Adam, O., T. Schneider, and N. Harnik, 2014: Role of changes in mean temperatures versus temperature gradients in the recent widening of the Hadley circulation. J. Climate, 27, 7450-7461, https://doi.org/10.1175/JCLI-D-14-00140.1

Allen, R. J., and O. Ajoku, 2016: Future aerosol reductions and widening of the northern tropical belt. J. Geophys. Res. Atmos., 121, 6765-6786, https://doi.org/10.1002/2016JD024803.

- and M. Kovilakam, 2017: The role of natural climate variability in recent tropical expansion. J. Climate, 30, 6329-6350, https://doi.org/10.1175/JCLI-D-16-0735.1.

, S. C. Sherwood, J. R. Norris, and C. S. Zender, 2012: Recent Northern Hemisphere tropical expansion primarily driven by black carbon and tropospheric ozone. Nature, 485, 350-354, https://doi.org/10.1038/nature11097.

_ J. R. Norris, and M. Kovilakam, 2014: Influence of anthropogenic aerosols and the Pacific Decadal Oscillation on tropical belt width. Nat. Geosci., 7, 270-274, https://doi.org/ 10.1038/ngeo2091.

Archer, C. L., and K. Caldeira, 2008: Historical trends in the jet streams. Geophys. Res. Lett., 35, L08803, https://doi.org/10.1029/ 2008 GL033614.

Bond, T. C., and Coauthors, 2013: Bounding the role of black carbon in the climate system: A scientific assessment. J. Geophys. Res. Atmos., 118, 5380-5552, https://doi.org/10.1002/jgrd.50171.

D'Agostino, R., P. Lionello, O. Adam, and T. Schneider, 2017: Factors controlling Hadley circulation changes from the Last Glacial Maximum to the end of the 21st century. Geophys. Res. Lett., 44, 8585-8591, https://doi.org/10.1002/2017GL074533.

Davis, N., and T. Birner, 2017: On the discrepancies in tropical belt expansion between reanalyses and climate models and among tropical belt width metrics. J. Climate, 30, 1211-1231, https:// doi.org/10.1175/JCLI-D-16-0371.1.

Davis, S. M., and K. H. Rosenlof, 2012: A multidiagnostic intercomparison of tropical-width time series using reanalyses and satellite observations. J. Climate, 25, 1061-1078, https:// doi.org/10.1175/JCLI-D-11-00127.1.

Dee, D. P., and Coauthors, 2011: The ERA-Interim reanalysis: Configuration and performance of the data assimilation system. Quart. J. Roy. Meteor. Soc., 137, 553-597, https://doi.org/10.1002/qj.828.

Farrera, I., and Coauthors, 1999: Tropical climates at the Last Glacial Maximum: A new synthesis of terrestrial palaeoclimate data. I. Vegetation, lake-levels and geochemistry. Climate Dyn., 15, 823856, https://doi.org/10.1007/s003820050317.
Frierson, D. M. W., J. Lu, and G. Chen, 2007: Width of the Hadley cell in simple and comprehensive general circulation models. Geophys. Res. Lett., 34, L18804, https://doi.org/10.1029/ 2007GL031115.

Fu, Q., C. M. Johanson, J. M. Wallace, and T. Reichler, 2006: Enhanced mid-latitude tropospheric warming in satellite measurements. Science, 312, 1179, https://doi.org/10.1126/ science. 1125566.

Gersonde, R., and Coauthors, 2003: Last glacial sea surface temperatures and sea-ice extent in the Southern Ocean (AtlanticIndian sector): A multiproxy approach. Paleoceanogr. Paleoclimatol., 18, 1061, https://doi.org/10.1029/2002PA000809.

Grassi, B., G. Redaelli, P. O. Canziani, and G. Visconti, 2012: Effects of the PDO phase on the tropical belt width. J. Climate, 25, 3282-3290, https://doi.org/10.1175/JCLI-D-11-00244.1.

Held, I. M., and A. Y. Hou, 1980: Nonlinear axially symmetric circulations in a nearly inviscid atmosphere. J. Atmos. Sci., 37, 515-533, https://doi.org/10.1175/1520-0469(1980)037<0515: NASCIA $>2.0 . \mathrm{CO} ; 2$.

$\mathrm{Hu}, \mathrm{Y}$., and Q. Fu, 2007: Observed poleward expansion of the Hadley circulation since 1979. Atmos. Chem. Phys., 7, 52295236, https://doi.org/10.5194/acp-7-5229-2007.

- L. Tao, and J. Liu, 2013: Poleward expansion of the Hadley circulation in CMIP5 simulations. Adv. Atmos. Sci., 30, 790795, https://doi.org/10.1007/s00376-012-2187-4

-, H. Huang, and C. Zhou, 2018: Widening and weakening of the Hadley circulation under global warming. Sci. Bull., 63 , 640-644, https://doi.org/10.1016/j.scib.2018.04.020.

Jiang, D., Z. Tian, X. Lang, M. Kageyama, and G. Ramstein, 2015: The concept of global monsoon applied to the last glacial maximum: A multi-model analysis. Quat. Sci. Rev., 126, 126139, https://doi.org/10.1016/j.quascirev.2015.08.033.

Kalnay, E., and Coauthors, 1996: The NCEP/NCAR 40-Year Reanalysis Project. Bull. Amer. Meteor. Soc., 77, 437-471, https:// doi.org/10.1175/1520-0477(1996)077<0437:TNYRP>2.0.CO;2.

Kanamitsu, M., W. Ebisuzaki, J. Woollen, S.-K. Yang, J. J. Hnilo, M. Fiorino, and G. L. Potter, 2002: NCEP-DOE AMIP-II Reanalysis (R-2). Bull. Amer. Meteor. Soc., 83, 1631-1644, https://doi.org/10.1175/BAMS-83-11-1631.

Kang, S. M., and L. M. Polvani, 2011: The interannual relationship between the latitude of the eddy-driven jet and the edge of the Hadley cell. J. Climate, 24, 563-568, https://doi.org/10.1175/ 2010JCLI4077.1.

Karnauskas, K. B., and C. C. Ummenhofer, 2014: On the dynamics of the Hadley circulation and subtropical drying. Climate Dyn., 42, 2259-2269, https://doi.org/10.1007/s00382-014-2129-1.

Kohfeld, K. E., R. M. Graham, A. M. de Boer, L. C. Sime, E. W. Wolff, C. Le Quéré, and L. Bopp, 2013: Southern Hemisphere westerly wind changes during the Last Glacial Maximum: Paleo-data synthesis. Quat. Sci. Rev., 68, 76-95, https://doi.org/ 10.1016/j.quascirev.2013.01.017.

Laîné, A., and Coauthors, 2009: Northern hemisphere storm tracks during the last glacial maximum in the PMIP2 oceanatmosphere coupled models: Energetic study, seasonal cycle, precipitation. Climate Dyn., 32, 593-614, https://doi.org/ 10.1007/s00382-008-0391-9.

Lucas, C., and H. Nguyen, 2015: Regional characteristics of tropical expansion and the role of climate variability. J. Geophys. Res. Atmos., 120, 6809-6824, https://doi.org/ 10.1002/2015JD023130.

, - _ , and B. Timbal, 2012: An observational analysis of Southern Hemisphere tropical expansion. J. Geophys. Res., 117, D17112, https://doi.org/10.1029/2011JD017033. 
Mantsis, D. F., S. Sherwood, R. Allen, and L. Shi, 2017: Natural variations of tropical width and recent trends. Geophys. Res. Lett., 44, 3825-3832, https://doi.org/10.1002/2016GL072097.

McCabe, G. J., M. P. Clark, and M. C. Serreze, 2001: Trends in Northern Hemisphere surface cyclone frequency and intensity. J. Climate, 14, 2763-2768, https://doi.org/10.1175/ 1520-0442(2001)014<2763:TINHSC $>2.0$. CO;2.

Min, S.-K., and S.-W. Son, 2013: Multimodel attribution of the Southern Hemisphere Hadley cell widening: Major role of ozone depletion. J. Geophys. Res. Atmos., 118, 3007-3015, https://doi.org/10.1002/jgrd.50232.

Nakamura, H., and A. Shimpo, 2004: Seasonal variations in the Southern Hemisphere storm tracks and jet streams as revealed in a reanalysis dataset. J. Climate, 17, 1828-1844, https://doi.org/ 10.1175/1520-0442(2004)017<1828:SVITSH>2.0.CO;2.

_, T. Sampe, Y. Tanimoto, and A. Shimpo, 2004: Observed associations among storm tracks, jet streams and midlatitude oceanic fronts. Earth's Climate: The Ocean-Atmosphere Interaction, Geophys. Monogr., Vol. 147, Amer. Geophys. Union, 329-345, https://doi.org/10.1029/147GM18.

Nguyen, H., A. Evans, C. Lucas, I. Smith, and B. Timbal, 2013: The Hadley circulation in reanalyses: Climatology, variability, and change. J. Climate, 26, 3357-3376, https://doi.org/10.1175/ JCLI-D-12-00224.1.

Oster, J. L., D. E. Ibarra, M. J. Winnick, and K. Maher, 2015: Steering of westerly storms over western North America at the Last Glacial Maximum. Nat. Geosci., 8, 201-205, https://doi.org/ 10.1038/ngeo2365.

Polvani, L. M., D. W. Waugh, G. J. P. Correa, and S.-W. Son, 2011: Stratospheric ozone depletion: The main driver of twentiethcentury atmospheric circulation changes in the Southern Hemisphere. J. Climate, 24, 795-812, https://doi.org/10.1175/ 2010JCLI3772.1.

Reichler, T., M. Dameris, and R. Sausen, 2003: Determining the tropopause height from gridded data. Geophys. Res. Lett., 30, 2042, https://doi.org/10.1029/2003GL018240.

Rienecker, M. M., and Coauthors, 2011: MERRA: NASA's Modern-Era Retrospective Analysis for Research and Applications. J. Climate, 24, 3624-3648, https://doi.org/10.1175/ JCLI-D-11-00015.1.

Salmon, R., I. M. Held, J. Fields, and J.-L. Thiffeault, 2001: The general circulation of the atmosphere: 2000 program of study in geophysical fluid dynamics. Woods Hole Oceanographic Institution Tech. Rep. WHOI-2001-03, 179 pp., https:// darchive.mblwhoilibrary.org/handle/1912/15.

Seidel, D. J., and W. J. Randel, 2007: Recent widening of the tropical belt: Evidence from tropopause observations. J. Geophys. Res., 112, D20113, https://doi.org/10.1029/ 2007JD008861.
Solomon, A., L. M. Polvani, D. W. Waugh, and S. M. Davis, 2016: Contrasting upper and lower atmospheric metrics of tropical expansion in the Southern Hemisphere. Geophys. Res. Lett., 43, $10496-10503$, https://doi.org/10.1002/ 2016GL070917.

Son, S.-W., N. F. Tandon, L. M. Polvani, and D. W. Waugh, 2009: Ozone hole and Southern Hemisphere climate change. Geophys. Res. Lett., 36, L15705, https://doi.org/10.1029/ 2009GL038671.

— from Last Glacial Maximum to future climate. J. Climate, $\mathbf{3 1}$, 267-281, https://doi.org/10.1175/JCLI-D-17-0328.1.

Tao, L., Y. Hu, and J. Liu, 2016: Anthropogenic forcing on the Hadley circulation in CMIP5 simulations. Climate Dyn., 46, 3337-3350, https://doi.org/10.1007/s00382-015-2772-1.

Taylor, K. E., 2001: Summarizing multiple aspects of model performance in a single diagram. J. Geophys. Res., 106, 71837192, https://doi.org/10.1029/2000JD900719.

_ R. J. Stouffer, and G. A. Meehl, 2012: An overview of CMIP5 and the experiment design. Bull. Amer. Meteor. Soc., 93, 485498, https://doi.org/10.1175/BAMS-D-11-00094.1.

Vallis, G. K., 2006: Atmospheric and Oceanic Fluid Dynamics: Fundamentals and Large-scale Circulation. Cambridge University Press, 773 pp.

Walker, C. C., and T. Schneider, 2006: Eddy influences on Hadley circulations: Simulations with an idealized GCM. J. Atmos. Sci., 63, 3333-3350, https://doi.org/10.1175/JAS3821.1.

Wang, N., D. Jiang, and X. Lang, 2018: Northern westerlies during the Last Glacial Maximum: Results from CMIP5 simulations. J. Climate, 31, 1135-1153, https://doi.org/ 10.1175/JCLI-D-17-0314.1.

Waugh, D. W., and Coauthors, 2018: Revisiting the relationship among metrics of tropical expansion. J. Climate, 31, 75657581, https://doi.org/10.1175/JCLI-D-18-0108.1.

Wilcox, L. J., E. J. Highwood, and N. J. Dunstone, 2013: The influence of anthropogenic aerosol on multi-decadal variations of historical global climate. Environ. Res. Lett., 8, 024033, https://doi.org/10.1088/1748-9326/8/2/024033.

WMO, 1957: Meteorology-A three-dimensional science: Second session of the commission for aerology. WMO Bull., 4, 134-138.

Yan, Z., and N. Petit-Maire, 1994: The last $140 \mathrm{ka}$ in the AfroAsian arid/semi-arid transitional zone. Palaeogeogr. Palaeoclimatol. Palaeoecol., 110, 217-233, https://doi.org/10.1016/ 0031-0182(94)90085-X.

Zhou, Y. P., K.-M. Xu, Y. C. Sud, and A. K. Betts, 2011: Recent trends of the tropical hydrological cycle inferred from Global Precipitation Climatology Project and International Satellite Cloud Climatology Project data. J. Geophys. Res., 116, D09101, https://doi.org/10.1029/2010JD015197. 